\title{
Predictive value of plasma and cerebrospinal fluid tumour necrosis factor- $\alpha$ and interleukin- $1 \beta$ concentrations on outcome of full term infants with hypoxic-ischaemic encephalopathy
}

\author{
Nihal Oygür, Özlem Sönmez, Osman Saka, Olcay Yeğin
}

\begin{abstract}
Aim-To determine the predictive value of plasma and cerebrospinal fluid (CSF) tumour necrosis factor- $\alpha$ (TNF- $\alpha$ ) and interleukin-1 $\beta$ (IL-1 $\beta$ ) concentrations on the outcome of hypoxic-ischaemic encephalopathy (HIE) in full term infants. Methods-Thirty term infants with HIE were included in the study. HIE was classified according to the criteria of Sarnat and Sarnat. Blood and CSF were obtained within the first 24 hours of life and stored until assay. Five infants died soon after hypoxic insult. Neurological examinations and Denver Developmental Screening Test (DDST) were performed at 12 months in the survivors.
\end{abstract}

Results-At the age of 12 months neurological examination and DDST showed that 11 infants were normal; 14 had abnormal neurological findings and/or an abnormal DDST result. Eleven normal infants were classified as group 1 and 19 infants (14 with abnormal neurological findings and/or an abnormal DDST and five who died) as group 2. CSF IL-1 $\beta$ and TNF- $\alpha$ concentrations in group 2 were significantly higher than those in group 1. Plasma IL-1 $\beta$ and TNF- $\alpha$ concentrations were not significantly different between the two groups. IL-1 $\beta$, but not TNF- $\alpha$ concentrations, in group 2 were even higher than those in group 1, although nonsurvivors were excluded from group 2 . When the patients were evaluated according to the stages of Sarnat, the difference in the three groups was again significant. Patients whose CSF samples were taken within 6 hours of the hypoxic insult had higher IL-1 $\beta$ and TNF- $\alpha$ concentrations than the patients whose samples were taken after 6 hours.

Conclusions-Both cytokines probably contribute to the damage sustained by the central nervous system after hypoxic insult. IL-1 $\beta$ seems to be a better predictor of HIE than TNF- $\alpha$.

(Arch Dis Child Fetal Neonatal Ed 1998;79:F190-F193)

Keywords: hypoxic-ischaemic encephalopathy; cytokine; tumour necrosis factor- $\alpha$; interleukin- $1 \beta$

Hypoxic-ischaemic brain damage in the fetus and neonates, is a major cause of acute mortality and chronic neurological disability in survivors. The association between the degree of hypoxic insult and the adverse outcome is still not clear. Similar degrees of insult may completely spare one child and devastate another, so very sensitive parameters are needed to be able to predict outcome in infants with birth asphyxia. ${ }^{1-3}$

TNF- $\alpha$ and IL- $1 \beta$ are two important cytokines released mainly by mononuclear cells and macrophages in response to infection and tissue injury. Both of them have important roles in metabolic abnormalities and multiple organ failure detected in infection; they are also good predictors of outcome in sepsis. ${ }^{4}$ The role of these two cytokines in tissue injury due to perinatal asphyxia has also been investigated in some experimental studies. The results suggest that they may have important roles in the response of the neonatal brain to acute hypoxic-ischaemic injury. ${ }^{6-8}$ However, it is not clear whether they have the same effect in human neonatal brain after perinatal asphyxia and whether they can accurately predict prognosis. This study aimed to determine if plasma and cerebrospinal fluid concentrations of IL- $1 \beta$ and TNF- $\alpha$ can be predictors of early prognosis in neonates after HIE.

\section{Methods}

The study was approved by the Akdeniz University Medical School Ethics Committee. Thirty infants with a gestational age of between 38 and 42 weeks were included in the study. Infants were accepted as eligible if they had at least three of the following criteria: signs of fetal distress, as indicated by late decelerations on fetal monitoring or by meconium staining of the amniotic fluid; Apgar score of $<5$ at 5 minutes; requirement for resuscitation and/or intubation in the delivery room; arterial cord blood $\mathrm{pH}<7.2$; multiorgan failure; and one or more abnormal neurological signs such as irritability, tremors, altered consciousness, abnormalities of tone and convulsions in the first 24 hours of life.

HIE was classified as mild (1), moderate (2), or severe (3), according to the criteria of Sarnat and Sarnat. ${ }^{9}$

After informed parental consent had been obtained, blood and cerebrospinal fluid samples from the infants were obtained within the first 24 hours of postnatal life. None of them had evidence of infection at the time. Infants whose blood or CSF cultures became positive after the samples were taken, were excluded from the study. Five infants died soon after diagnosis. Others were followed up every 
Table 1 Results of TNF- $a, I L-1 \beta$ concentrations, DDST, and outcome of group 1

\begin{tabular}{|c|c|c|c|c|c|c|c|c|}
\hline Case No & Grade* & DDSTH & Outcome & Time $e^{\star \star}$ & $p T N F+$ & $c s f T N F t$ & $p I L-1 \beta \dagger$ & $c s f I L-1 \beta \dagger$ \\
\hline 1 & 1 & $\mathrm{~N}$ & Normal & 2 & 15.6 & 27 & 0.125 & 0.37 \\
\hline 2 & 1 & $\mathrm{~N}$ & Normal & 12 & 142 & 15.6 & 0.63 & 0.23 \\
\hline 3 & 1 & $\mathrm{~N}$ & Normal & 2 & 15.6 & 15.6 & 6.84 & 1.7 \\
\hline 4 & 1 & $\mathrm{~N}$ & Normal & 1 & 63 & 249 & 0.59 & 0.59 \\
\hline 5 & 1 & $\mathrm{~N}$ & Normal & 2 & 114 & 27 & 0.27 & 0.125 \\
\hline 6 & 1 & $\mathrm{~N}$ & Normal & 12 & 15.6 & 91 & 0.67 & 0.48 \\
\hline 7 & 2 & $\mathrm{~N}$ & Normal & 2 & 31 & 65 & 0.47 & 0.25 \\
\hline 8 & 1 & $\mathrm{~N}$ & Normal & 12 & 16 & 35 & 0.65 & 1.5 \\
\hline 9 & 1 & $\mathrm{~N}$ & Normal & 3 & 31 & 37 & 1.8 & 3.3 \\
\hline 10 & 1 & $\mathrm{~N}$ & Normal & 1 & 102 & 80 & 0.29 & 0.125 \\
\hline 11 & 1 & $\mathrm{~N}$ & Normal & 1 & 25 & 42 & 0.46 & 1.3 \\
\hline Mean (SEM) & & & & $4.55(1.45)$ & $51.89(13.65)$ & $62.2(20.14)$ & $1.16(0.58)$ & $0.90(0.29)$ \\
\hline Median & & & & & 31 & 37 & 0.59 & 0.48 \\
\hline
\end{tabular}

^ HIE scoring according to Sarnat and Sarnat (1: mild; 2: moderate; 3: severe).

$\star \star$ Postnatal time, the samples were taken.

† All cytokine concentrations are $\mathrm{pg} / \mathrm{ml}$.

+† Denver Developmental Screening Test (N: normal, F: failure in at least two parameters of DDST).

month by routine physical examination. Their detailed neurological examinations and Denver Developmental Screening Tests (DDST) were performed at 12 months of age.

Blood and CSF samples were obtained simultaneously from each subject. CSF samples were collected aseptically into sterile tubes and directly frozen at $-60^{\circ} \mathrm{C}$ until assay. Blood samples were also collected into sterile tubes containing liquid ethylenediaminetetra-acetic acid. Tubes were centrifuged at $4^{\circ} \mathrm{C}(800 \times g)$ for 10 minutes. After centrifugation plasma was removed and frozen at $-50^{\circ} \mathrm{C}$ until assay.

Commercially available enzyme linked immunosorbent assay kits, specific for TNF- $\alpha$ (Milena, DPC Biermann GmbH, Germany) and IL-1 $\beta$ (High Sensitive, Research and Diagnostics, Minneapolis, $\mathrm{MN}$ ) were used to assess the concentrations of these cytokines. Briefly, standards or samples containing the tested cytokine reacted with monoclonal antibodies coated on a plastic well and, after incubation and washing to remove any unbound antibody-enzyme reagent, the detection reagent (substrate) was added and incubated. The reaction was blocked with sulphuric acid and the plate was read at the appropriate wavelength. A standard curve was plotted and tested cytokine concentrations were determined by interpolation from this curve. All samples were tested in duplicate. The minimal detection level was $6 \mathrm{pg} / \mathrm{ml}$ and the standard curve was between 15.6 and $1000 \mathrm{pg} / \mathrm{ml}$ for TNF- $\alpha$; they were $0.1 \mathrm{pg} / \mathrm{ml}$ and $0.125-8 \mathrm{pg} / \mathrm{ml}$ for IL- $1 \beta$.

There were wide variations in TNF- $\alpha$ and IL-1 $\beta$ concentrations in patients so the MannWhitney U test or the Kruskal-Wallis test were applied, as appropriate, to analyse differences among groups; $p<0.05$ was regarded as significant.

\section{Results}

Eleven infants had grade 1, 10 grade 2, and nine grade $3 \mathrm{HIE}$ according to Sarnat. Five infants died within a few days of postnatal life. Of 25 infants, 11 had normal neurological and DDST results, 14 had abnormal neurological findings and/or abnormal DDST at the age of 12 months. Thus 11 infants were classified as group 1 and 19 infants (14 abnormal neurological findings and/or abnormal DDST and five died) as group 2.

Plasma IL- $1 \beta$ and TNF- $\alpha$ concentrations did not show significant differences between the two groups $(p=0.182$ for IL-1 $\beta$ and $\mathrm{p}=0.342$ for $\mathrm{TNF}-\alpha)$. CSF IL- $1 \beta$ concentrations in group 2 were significantly higher than in group $1(p=0.002)$. Similarly, high $\mathrm{TNF}-\alpha$

Table 2 Results of TNF- $\alpha, I L-1 \beta$ concentrations, DDST, and outcome of group 2

\begin{tabular}{|c|c|c|c|c|c|c|c|c|}
\hline Case No & Grade * & DDSTH & Outcome & Time** & $p T N F+$ & $c s f T N F t$ & $p I L-1 \beta \dagger$ & $c s f I L-1 \beta \dagger$ \\
\hline 1 & 3 & $\mathrm{~F}$ & Spastic cerebral palsy & 4 & 24 & 56 & 5.3 & 3.9 \\
\hline 2 & 2 & $\mathrm{~F}$ & Mental motor retardation & 6 & 29 & 41 & 0.44 & 1.8 \\
\hline 3 & 1 & $\mathrm{~F}$ & Mental motor retardation & 12 & 15.6 & 32 & 0.57 & 0.125 \\
\hline 4 & 2 & $\mathrm{~F}$ & Mental motor retardation & 8 & 56 & 39 & 3.9 & 4.3 \\
\hline 5 & 3 & Died on day 5 & & 3 & 247 & 75 & 8 & 5.4 \\
\hline 6 & 2 & $\mathrm{~F}$ & Spastic cerebral palsy & 1 & 22 & 468 & 4.1 & 7.8 \\
\hline 7 & 3 & $\mathrm{~F}$ & Spastic cerebral palsy & 1 & 39 & 73 & 0.28 & 4.8 \\
\hline 8 & 3 & Died on day 4 & & 2 & 1000 & 83 & 7.48 & 6.6 \\
\hline 9 & 2 & $\mathrm{~F}$ & Spastic cerebral palsy & 12 & 37 & 131 & 2.1 & 3.5 \\
\hline 10 & 3 & $\mathrm{~F}$ & Spastic cerebral palsy & 12 & 45 & 100 & 1.8 & 4.7 \\
\hline 11 & 3 & Died on day 6 & & 4 & 79 & 123 & 8 & 4.8 \\
\hline 12 & 3 & Died on day 3 & & 6 & 157 & 356 & 2.16 & 8 \\
\hline 13 & 2 & $\mathrm{~F}$ & Cerebral palsy & 24 & 42 & 27 & 0.3 & 1.8 \\
\hline 14 & 3 & $\mathrm{~F}$ & Mental motor retardation & 10 & 99 & 69 & 0.125 & 2.9 \\
\hline 15 & 2 & $\mathrm{~F}$ & Mental motor retardation & 12 & 25 & 81 & 0.26 & 0.125 \\
\hline 16 & 3 & $\mathrm{~F}$ & Mental motor retardation & 1 & 45 & 58 & 6.5 & 7.4 \\
\hline 17 & 2 & $\mathrm{~F}$ & Spastic cerebral palsy & 6 & 15.6 & 44 & 0.35 & 0.125 \\
\hline 18 & 1 & $\mathrm{~F}$ & Mental motor retardation & 3 & 98 & 107 & 3.7 & 5.8 \\
\hline 19 & 3 & Died on day 5 & & 2 & 40 & 255 & 0.62 & 3.6 \\
\hline Mean (SEM) & & & & $6.79(1.33)$ & $120.8(53.41)$ & $116.73(26.99)$ & $2.94(0.66)$ & $4.07(0.57)$ \\
\hline Median & & & & & 42 & 75 & 2.1 & 4.3 \\
\hline
\end{tabular}

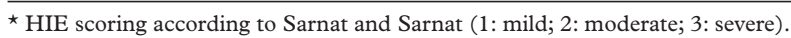

$\star \star$ Postnatal time, the samples were taken.

† All cytokine concentrations are $\mathrm{pg} / \mathrm{ml}$.

t† Denver Developmental Screening Test (N: normal, F: failure in at least two parameters of DDST). 
Table 3 Cerebrospinal fluid TNF- $a$ and IL-1 $\beta$ concentrations of group 1 and 2

\begin{tabular}{lllll}
\hline & Group 1 $(n=11)$ & Group 2a $(n=14) *$ & Group 2b $(n=5) \dagger$ & ptt \\
\hline TNF- $\alpha(\mathrm{CSF})^{\star}$ & & & & \\
Mean (SEM) & $62.2(20.14)$ & $94.71(29.84)$ & $178(54.89)$ & 0.01 \\
Median & 37 & 63.5 & 123 & $(0.1) \ddagger$ \\
Range & $15.6-248$ & $27-468$ & $75-356$ & \\
IL-1 1 (CSF) & & & & \\
Mean (SEM) & $0.90(0.29)$ & $3.5(0.67)$ & $5.68(0.75)$ & 0.002 \\
Median & 0.48 & 3.7 & 5.4 & $(0.01) \ddagger$ \\
Range & $0.125-3.3$ & $0.125-7.4$ & $3.6-8.0$ & \\
\hline
\end{tabular}

$\star$ All cytokine concentrations are $\mathrm{pg} / \mathrm{ml}$.

$\star \star$ Group 2a, survivors.

† Group 2b, non-survivors.

t† Significance between the 3 groups ( $\mathrm{p}<0.05$ as significant).

$\ddagger$ Significance between group 1 and group $2 \mathrm{a}(\mathrm{p}<0.05$ as significant $)$.

concentrations were detected in the CSF of group 2 compared with group $1(\mathrm{p}=0.02)$ (tables 1 and 2). High CSF IL-1 $\beta$ (5.4, 6.6, $4.8,8.0,3.6 \mathrm{pg} / \mathrm{ml})$ and $\mathrm{TNF}-\alpha(75,83,123$, $356,255 \mathrm{pg} / \mathrm{ml}$ ) concentrations were detected in all the patients who died.

IL- $1 \beta$ concentrations in group 2 were still higher than those of group 1 even though nonsurvivors were excluded from group 2 as they had very high cytokine concentrations. The difference between the two groups was insignificant for CSF TNF- $\alpha$ when non-survivors were excluded from group 2 ( $p=0.01$ for IL- $1 \beta$ and $\mathrm{p}=0.1$ for $\mathrm{TNF}-\alpha$ ) (table 3 ). The positive and negative predictive values were $80 \%$ and $70 \%$ for IL- $1 \beta$, respectively, when nonsurvivors were included, and $73 \%$ and $70 \%$ when they were not. The same values for TNF- $\alpha$ were $83 \%$ and $50 \%$, respectively, when they were included, whereas the values were $72 \%$ and $50 \%$, respectively, without them.

When the patients were evaluated according to the Sarnat classification, the CSF concentrations of TNF- $\alpha$ and IL- $1 \beta$ were 63.18 (18.98) and $1.3(0.49)$ in the patients with stage 1,112 (52.18) and $2.46(0.94)$ with stage 2, 124.8 (31.66) and $5.2(0.52)$ with stage 3 ; the difference among the three groups was significant $(p=0.04$ for $T N F-\alpha$ and $p=0.01$ for IL-1 $\beta$ ).

Patients whose CSF samples could be taken within the first six hours after hypoxic insult had higher concentrations of IL- $1 \beta$ and TNF- $\alpha$ than the patients whose samples were taken after six hours (5.0 (2.03) vs 2.49 (1.36) for IL-1 $\beta$ and 144.92 (99.12) vs 68.4 (26.82) for $\mathrm{TNF}-\alpha)$.

\section{Discussion}

Various studies have attempted to find a sensitive parameter that will accurately predict outcome in infants with perinatal asphyxia. Acidosis in umbilical cord blood and low Apgar scores are poor predictors of outcome after birth asphyxia. ${ }^{10-12}$ Cranial tomography, somatosensory evoked potentials, magnetic resonance imaging and spectroscopy, pulsed Doppler, cerebral function monitoring and early EEG monitoring seem to be useful for prognosis but the search continues for more sensitive parameters. ${ }^{13-16}$

In our study infants who had abnormal neurological findings and/or abnormal DDST at 1 year of age or who died soon after hypoxic insult had significantly higher CSF IL- $1 \beta$ and CSF TNF- $\alpha$ concentrations than the infants without any neurological sequelae. In contrast, plasma IL- $1 \beta$ and TNF- $\alpha$ concentrations did not show any significant difference among the two groups. These findings suggest that increased CSF IL- $1 \beta$ and TNF- $\alpha$ might be produced locally in CNS as a result of cerebral hypoxic insult.

The role of pro-inflammatory cytokines on neuronal damage after hypoxia were investigated in some experimental studies by measuring the cerebral tissue IL- $1 \beta$ and $T N F-\alpha$ content by reverse transcription, followed by polymerase chain reaction. In these studies marked transient stimulation of IL-1 $\beta$ mRNA expression was detected, peaking at 4-6 hours and returning to normal 24 hours after hypoxia. Similar transient increases were also detected in TNF- $\alpha$ mRNA expression. ${ }^{78}$ In another study of rat brains, Hagberg et $a l^{17}$ found that a transient increase in IL- $1 \beta$ bioactivity occurred after hypoxic insult, reaching a peak at 6 hours. Martin $e t a l^{18}$ showed the neuroprotective effect of interleukin-1 receptor antagonist (rhIL-1ra) against brain injury by administering it before and/or after hypoxic exposure. All these findings suggest that IL-1 $\beta$ and TNF- $\alpha$ may have important roles in the response of the neonatal brain to acute hypoxic-ischaemic injury.

To our knowledge TNF- $\alpha$ and IL- $1 \beta$ concentrations in the CSF of human neonates with hypoxic insult have not been studied before. In our study CSF IL-1 $\beta$ concentrations of the patients with abnormal DDST and/or neurological findings were still significantly higher than the patients without sequelae even though non-survivors were excluded from group 2 . The difference was insignificant for CSF TNF- $\alpha$ concentrations when non-survivors were excluded from group 2. This finding suggests that CSF IL- $1 \beta$ seems to be more valuable than TNF- $\alpha$ in predicting the prognosis after hypoxia especially in infants who survive. Similar to the studies of Hagberg ${ }^{17}$ and Szaflarski, ${ }^{7}$ we found higher concentrations in the CSF samples taken during the first six hours after hypoxia than the samples taken subsequently, which suggests that the difference between the groups would have been even greater if we could have obtained all the samples in the first six hours after hypoxic insult.

Interleukin-6 concentrations in CSF after hypoxia were evaluated and were significantly higher in the patients with adverse outcome. ${ }^{19}$ IL-6 is known to have neurotrophic and neuroprotective effects; it also opposes the effects of TNF- $\alpha$ and IL- $1 \beta$, both by inhibiting their synthesis and by stimulating the generation of their naturally occurring antagonists. ${ }^{20-22}$ So it is not clear whether IL-6 participates in the degeneration or repair of neurons after ischaemic brain injury. We did not analyse IL-6 concentrations in our patients, but we believe detecting three of these cytokines at the same time helps us to understand the relation between them and their role in the pathogenesis of tissue injury after hypoxia.

According to Azzopardi et al, ${ }^{23}$ neonates subjected to transient hypoxia-ischaemia during 
an episode of birth asphyxia seem relatively normal soon after resuscitation, but show evidence of delayed cerebral injury some hours later. The mechanism of delayed injury is still unclear, but in the brains of infants dying after birth asphyxia, cells can be detected which show the hallmarks of apoptotic death. TNF- $\alpha$ is thought to be a potent activator of apoptosis and can trigger apoptosis by activating sphingomyelinase, leading to an increase in cytosolic concentrations of ceramide, a potent inducer of apoptosis. $^{24}$

Our findings suggest that these two cytokines or at least TNF- $\alpha$ may be responsible for the biphasic process of cerebral injury and adverse neurological outcome or death by inducing apoptosis. The detection of very high CSF TNF- $\alpha$ concentrations in the patients who died some time after hypoxic insult supports this hypothesis.

In conclusion, both cytokines seem to have important roles in damage to the CNS, and IL-1 $\beta$ seems to be a better predictor of outcome in HIE, but more investigations are required to understand the role of these cytokines in cerebral injury caused by hypoxic insult.

The study was supported by the Akdeniz University Research Foundation

1 Vannuci RC. Hypoxia-ischemia: Clinical aspects. In: Fanaroff AA, Martin RJ, eds. Neonatal-Perinatal Medicine. Diseases of the Fetus and Infant. 6th edn. Philadelphia: MosbyYear Book, 1997:877-91

Pasternak JF. Hypoxic-ischemic brain damage in the term infant. Pediatr Clin North Am 1993;40:1061-71.

3 Robertson CMT, Finer NN. Long term follow-up of term neonates with perinatal asphyxia. Clin Perinatol 1993;20:483-90.

4 Bont ESJM, Martens A, Raan J, et al. Tumor necrosis factor-alpha, interleukin-1B and interleukin- 6 plasma levels in neonatal sepsis. Pediatr Res 1993;33:380-3.

5 Özdemir A, Oygür N, Gültekin M, Copkun M, Yeğin O. Neonatal tumor necrosis factor, interleukin-1alpha, interleukin-1B and interleukin-6 response to Infection. Am $\mathcal{F}$ Perinatol 1994;11:282-4.

6 Nelson KB, Emery ES. Birth asphyxia and the neonatal brain: What do we know and when do we know it? Clin brain: What do we know
Perinatol 1993;20:327-44.
7 Szaflarski J, Burtrum D, Silverstein FS. Cerebral hypoxiaischemia stimulates cytokine gene expression in perinatal ischemia stimulates cytokine ge
rats. Stroke 1995;26:1093-100.

8 Silverstein FS, Barks JD, Hagan P, Liu XH, Ivacko J, Szaflarski J. Cytokines and perinatal brain injury. Neurochem Int 1997;30:375-83.

9 Sarnat HB, Sarnat MS. Neonatal encephalopathy following fetal distress: a clinical and electrophysiological study. Arch Neurol 1976;33:696-705.

10 Fee SC, Malee K, Deddish R, Minogue JP, Min D, Socol ML. Severe acidosis and subsequent neurologic status. $\mathrm{Am}$ f Obset Gynecol 1990;162:802-6.

11 Nelson KB, Ellenberg JH. Apgar scores as predictors of chronic neurologic disability. Pediatrics $1981 ; 68: 36-44$

12 Carter BS, MAJ, Haverkamp AD, Merestein GB. The definition of acute asphyxia. Clin Perinatol 1993;20:287-303.

13 Hellström-Westas L, Rosen I, Svenningsen NW. Predictive value of early continuous amplitude integrated EEG recordings on outcome after severe birth asphyxia in full term infants. Arch Dis Child 1995;72:F34-38.

14 Eken P, Toet MC, Groenendaal F, de Vries LS. Predictive value of early neuroimaging, pulsed Doppler and neurophysiology in fullterm infants with hypoxic-ischaemic encephalopathy. Arch Dis Child 1995;73:F75-80.

15 Martin E, Barkovich AJ. Magnetic resonance imaging in perinatal asphyxia. Arch Dis Child 1995;72:F62-70.

16 Rutherford M, Pennock J, Schwieso J, Cowan F, Dubowitz L. Hypoxic-ischaemic encephalopathy:early and late magnetic resonance imaging findings in relation to outcome. Arch Dis Child 1996;75:F145-51.

17 Hagberg H, Gilland E, Bona E, et al. Enhanced expression of interleukin (IL)-1 and IL-6 messenger RNA and bioactive protein after hypoxia-ischemia in neonatal rats. Pediatr Res 1996;40:603-9.

18 Martin D, Chinookoswong N, Miller G. The interleukin-1 receptor antagonist (rhIL-1ra) protects against cerebral infarction in a rat model of hypoxia-ischemia. Exp Neurol 1994;130:362-7.

19 Ancel AM, Alix-AG, Salcedo DP, Cabanas F, Valcarce M, Quero J. Interleukin-6 in the cerebral fluid after perinatal asphyxia is related to early and late neurologic manifestations. Pediatrics 1997;100:789-94.

20 Tilg H, Trehu E, Atkins MB, Dinarello CA, Mier JW. Interleukin-6(IL-6) as an antiinflammatory cytokine: Induction of circulating IL-1 receptor antagonist and soluble tumor necrosis factor receptor. Blood 1994;83:11318.

21 Selmaj KW, Farooq M, Norton WT, Raine CS, Brosnan CF. Proliferation of astrocytes in vitro in response to cytokines. A primary role for tumor necrosis factor. F Immunol 1990;144:129-35.

22 Rodriguez M, Pavelko KD, McKinney CW, Leibowitz JL. Recombinant human IL-6 supresses demyelination in a viral model of multihple sclerosis. $\mathcal{F}$ Immunol 1994;153:3811-21.

23 Azzopardi D, Wyatt JS, Cady EB, et al. Prognosis of newborn infants with hypoxic-Ischemic brain injury assessed by phosphorus magnetic resonance spectroscopy. Pediatr Res 1989;25:445-51.

24 Mehmet H, Edwards AD. Hypoxia, ischaemia, and apoptosis. Arch Dis Child 1996;75:F73-5. 